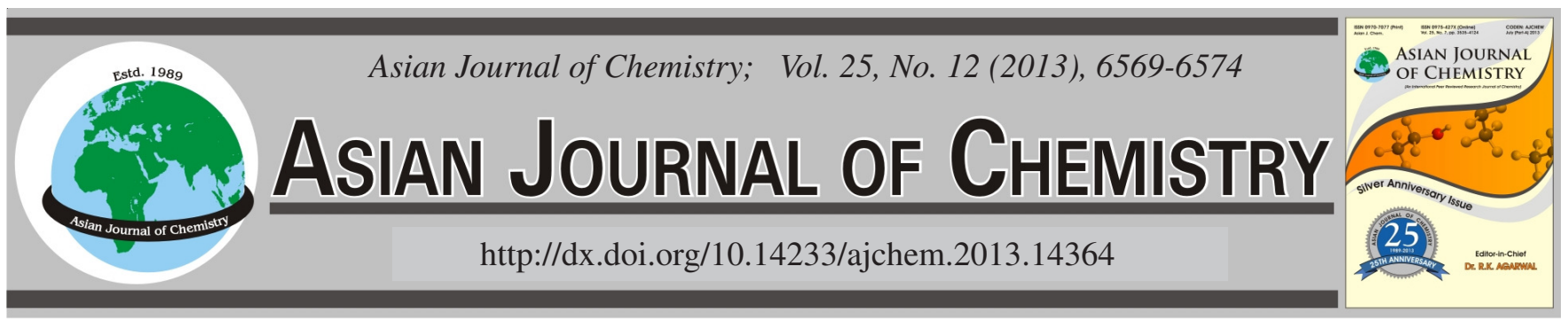

\title{
Synthesis of Thioxoquinazolin-4(3H)-one Derivatives Under Microwave and Ultrasonic Irradiation with Classical Heating
}

\section{Danah S. Al-Shamary ${ }^{1, *}$, Zeid A. Al-Othman ${ }^{2}$ and Monirah A. Al-Alshaikh ${ }^{1}$}

${ }^{1}$ Women Students-Medical Studies \& Sciences Sections, Department of Chemistry, College of Science, King Saud University, P.O. Box 22452, Riyadh 11495, Saudi Arabia

${ }^{2}$ Chemistry Department, College of Science, King Saud University, Riyadh 11451, Saudi Arabia

*Corresponding author: Tel/Fax: +966 75444554; E-mail: dana.933@ hotmail.com

\begin{abstract}
A series of thioxoquinazolin-4 $(3 H)$-one derivatives have been synthesized from hydrazide derivatives 1a-f using different electrophilic reagent, e.g., aryl isothiocyanate derivatives, carbon disulfide and aromatic aldehydes through nucleophilic substitution, condensation and cyclization reactions. Different methods were used to prepare compounds 2-6, including microwave irradiation, ultrasonic and classical heating. The compounds were characterized using various spectroscopic techniques. The synthesized compounds exhibited antibacterial activity.

Key Words: Thioxoquinazolin-4(3H)-one, Sonication, Microwave.
\end{abstract}

\section{INTRODUCTION}

Quinazolinone derivatives have been reported to show a variety of biological properties, such as antimicrobial ${ }^{1-6}$, anticonvulsant ${ }^{7-10}$, antitumor ${ }^{11-16}$, anticoccidial ${ }^{17}$, antidepressant ${ }^{18}$, antihistaminic $^{19,20}$, antiinflammatory ${ }^{21-24}$ and antiviral ${ }^{25,26}$ activities. Febrifugine and its analogue have been used as an anti malarial treatment $\mathrm{t}^{27-29}$. In addition, many thioxoquinazolin$4(3 H)$-one derivatives exhibit a considerable variety of activities, such as anticonvulsant ${ }^{30}$, anticancer ${ }^{31,32}$, antiulcer ${ }^{33}$ and antiinflammatory and have been used as therapeutic agents for neuro-protection ${ }^{34}$. Some novel thioxoquinazolinone derivatives have been synthesized using three different methods i.e., conventional synthesis, ultrasonic and microwave irradiation. The structures of these compounds were firmly established by well-defined IR, ${ }^{1} \mathrm{H}$ NMR, ${ }^{13} \mathrm{C}$ NMR, 2D NMR and ESI-MS spectroscopies. These compounds were then examined for antibacterial properties.

\section{EXPERIMENTAL}

The melting points (m.p.) were determined using an Electrothermal IA900 digital capillary melting point apparatus. The IR spectra were recorded in $\mathrm{KBr}$ discs on a Perkin Elmer 1000 FT-IR spectrophotometer $\left(v_{\max }\right.$ in $\left.\mathrm{cm}^{-1}\right)$. The ${ }^{1} \mathrm{H}$ NMR, ${ }^{13} \mathrm{C}$ NMR spectra and 2D NMR spectra were collected in DMSO- $d_{6}$ or $\left(\mathrm{CDCl}_{3}\right)$ using a JEOL-ECP-400 and on Bruker $600 \mathrm{MHz}$ spectrometer. The chemical shifts were reported as parts per million $(\delta$ ppm $)$ and the coupling constants $(J)$ are given in $\mathrm{Hz}$, tetramethyl silane (TMS) was used as an internal standard. The mass spectra $(\mathrm{m} / \mathrm{z}, \%)$ were obtained on an electro spray ionization (positive mode) LCMS, LCMS-MS and UPLC-MS/ MS. The ultrasonic irradiation was performed in a J.P. Selecta with a frequency of $50 / 60 \mathrm{~Hz}$ and a nominal power of $770 \mathrm{~W}$. The microwave experiments were performed in a $1000 \mathrm{~W}$ domestic microwave oven. The purity of all compounds was checked by TLC using glass plates coated with silica gel (G) and chloroform/methanol (9:1) as a solvent system. A UV lamp was used as a developing agent. Column chromatography: silica gel (70-230 mesh, Merck). Spectral data (IR, NMR, ${ }^{1} \mathrm{H}-$ ${ }^{13} \mathrm{C}-\mathrm{COSY}$ (HETCOR), DEPT 135 and mass spectra) confirmed the structures of the synthesized compounds.

The components were synthesized using three different methods: (A) Conventional synthesis, (B) ultrasonic synthesis and $(\mathrm{C})$ microwave irradiation.

2-\{[(6- or 7-Substituted-3-(4-substituted phenyl)-4-oxo-3,4dihydroquinazolin-2-yl) thio]acetyl\}-N-(4-substituted phenyl)hydrazinecarbothioamide (2a-c)

Method A for synthesis of (2a-c): An equimolar amount of compound $\mathbf{1 a}, \mathbf{1 b}$ or $\mathbf{1 e}(0.0008 \mathrm{~mol})$ and aryl isothiocyanate derivatives in absolute ethanol $(3 \mathrm{~mL})$ comprised the reaction mixture, which was heated under reflux for $1 \mathrm{~h}$. At the end of the reaction (monitored by TLC), the obtained solid was filtered and washed with ethanol. The solid product was pure and did not require recrystallization. 
Method B for synthesis of (2a-c): Equimolar amounts of compound $\mathbf{1 a}, \mathbf{1 b}$ or $\mathbf{1 e}(0.0008 \mathrm{~mol})$ and aryl isothiocyanate derivatives in absolute ethanol $(3 \mathrm{~mL})$ were placed into a $25 \mathrm{~mL}$ conical flask, which was then mixed and irradiated in the water bath of an ultrasonic cleaner at $80{ }^{\circ} \mathrm{C}$ for $15 \mathrm{~min}$ (TLC). The solid product was pure and did not require recrystallization.

Method C for synthesis of (2a-c): A few drops of absolute ethanol were added to an equimolar amount of compound 1a or 1e $(0.0002 \mathrm{~mol})$ and aryl isothiocyanate derivatives. Then, the reaction mixture was irradiated in a domestic microwave oven for $5 \mathrm{~min}$ (TLC) at a power of $300 \mathrm{~W}$. The solid product was pure and did not require recrystallization.

$\mathrm{N}$-Phenyl-2-(\{[3-(4-methylphenyl)-4-oxo-3,4-dihydroquinazolin-2-yl]thio\}acetyl)hydrazinecarbothioamide (2a): White fine scales, m.p. $218^{\circ} \mathrm{C}$, yield (\%) $86^{\mathrm{A}} 72^{\mathrm{B}} 36^{\mathrm{C}}$; IR $(\mathrm{KBr}$, $\left.v_{\max }, \mathrm{cm}^{-1}\right): 3317,3278,3180(\mathrm{NH}), 1687\left(\mathrm{C}=\mathrm{O}_{\text {lactam }}\right), 1659$ $\left(\mathrm{C}=\mathrm{O}_{\text {amide }}\right), 1464(\mathrm{C}=\mathrm{S}) ;{ }^{1} \mathrm{H}$ NMR $\left(\mathrm{DMSO}-d_{6}\right): 2.42(3 \mathrm{H}, \mathrm{s}$, $\left.\mathrm{CH}_{3}\right), 4.01$ (2H, s, $\left.\mathrm{CH}_{2}-\mathrm{S}-\right), 7.16\left(1 \mathrm{H}, \mathrm{t},{ }^{3} \mathrm{~J}=7.4, \mathrm{H}-4\right.$ '), 7.297.41 (8H, m, H-2', 3', 5', 6', 2", 3", 5", 6"), $7.47\left(1 \mathrm{H}, \mathrm{t},{ }^{3} \mathrm{~J}=8.1\right.$, H-6), $7.65\left(1 \mathrm{H}, \mathrm{d},{ }^{3} J=8.1, \mathrm{H}-8\right), 7.80\left(1 \mathrm{H}, \mathrm{t},{ }^{3} J=8.1, \mathrm{H}-7\right)$, $8.08\left(1 \mathrm{H}, \mathrm{d},{ }^{3} \mathrm{~J}=8.1, \mathrm{H}-5\right), 9.53,9.74,10.37$ (3H, br, s. NH groups); ${ }^{13} \mathrm{C}$ NMR spectral data of $\mathbf{2 a}$ were confirmed by $2 \mathrm{D}$ NMR ${ }^{1} \mathrm{H}^{13} \mathrm{C}-\mathrm{COSY}$ (HETCOR) and DEPT 135 experiments: $20.9\left(\mathrm{CH}_{3}\right), 35.0\left(\mathrm{CH}_{2}\right), 126.2(\mathrm{C}-6), 126.3(\mathrm{C}-8), 126.6$ (C-5), 128.1(C-4"), 134.9 (C-7), $157.1\left(\mathrm{C}=\mathrm{O}_{\text {lactam }}\right), 160.8$ (C-2), $166.9\left(\mathrm{C}=\mathrm{O}_{\text {amide }}\right), 180.7(\mathrm{C}=\mathrm{S}), 119.5,126.1(2 \mathrm{C})$, 129.1(2C), 129.2 (2C), 130.1(2C), 133.1, 138.9, 139.8, 147.1 ( $s p^{2}$ carbons); MS: m/z (\%) 476 (13) $[\mathrm{M}+\mathrm{H}]^{+}$ $\left(\mathrm{C}_{24} \mathrm{H}_{21} \mathrm{~N}_{5} \mathrm{O}_{2} \mathrm{~S}_{2}+\mathrm{H}\right), 309$ (100) [M+H-C $\left.\mathrm{C}_{7} \mathrm{H}_{8} \mathrm{~N}_{3} \mathrm{~S}-\mathrm{H}\right], 269$ (33) $\left[\mathrm{M}+\mathrm{H}-\mathrm{C}_{9} \mathrm{H}_{10} \mathrm{~N}_{3} \mathrm{OS}+\mathrm{H}\right], 208$ (24) $\left[\mathrm{C}_{9} \mathrm{H}_{10} \mathrm{~N}_{3} \mathrm{OS}\right]^{+}, 190$ (9) [208$\mathrm{OH}-\mathrm{H}]$.

2-\{[(7-Chloro-4-oxo-3-phenyl-3,4-dihydroquinazolin2-yl)thio]acetyl \}-N-4-methylhydrazinecarbothioamide (2b): white fine scales, m.p. $205^{\circ} \mathrm{C}$, yield (\%) $88^{\mathrm{A}} 54^{\mathrm{B}}$, IR $\left(\mathrm{KBr}, \mathrm{v}_{\max }, \mathrm{cm}^{-1}\right): 3314,3209,3115(\mathrm{NH}), 1701\left(\mathrm{C}=\mathrm{O}_{\text {lactam }}\right)$, $1660\left(\mathrm{C}=\mathrm{O}_{\text {amide }}\right), 1468(\mathrm{C}=\mathrm{S}) ;{ }^{1} \mathrm{H}$ NMR $\left(\mathrm{DMSO}-d_{6}\right): 2.28(3 \mathrm{H}$, s, $\left.\mathrm{CH}_{3}\right), 3.95\left(2 \mathrm{H}, \mathrm{s}, \mathrm{CH}_{2}-\mathrm{S}-\right), 7.09-7.20\left(4 \mathrm{H}, \mathrm{m}, \mathrm{H}-2^{\prime}, 6^{\prime}, 3^{\prime}\right.$, 5), 7.48-7.62 (6H, m, H-6, 3', 4', 5', 2", 6"), 7.76 (1H, s, H-8), $8.06\left(1 \mathrm{H}, \mathrm{d},{ }^{3} \mathrm{~J}=8.8, \mathrm{H}-5\right), 9.44,9.74,10.29$ (3H, br, s. NH groups); ${ }^{13} \mathrm{C}$ NMR: $20.6\left(\mathrm{CH}_{3}\right), 34.9\left(\mathrm{CH}_{2}\right), 118.4,125.7$, 125.9, 126.3 (2C), 128.6 (2C), 129.4 (2C), 129.7 (2C), 130.2, $134.5,135.5,136.3,139.4,148.1,158.8\left(\mathrm{C}=\mathrm{O}_{\text {lactam }}\right), 160.1$ $(\mathrm{C}-2), 166.9\left(\mathrm{C}=\mathrm{O}_{\text {amide }}\right), 180.8(\mathrm{C}=\mathrm{S})$ [one carbon with the baseline] ( $s p^{2}$ carbons); MS: m/z (\%) $510(9)[\mathrm{M}+\mathrm{H}]^{+}$ $\left(\mathrm{C}_{24} \mathrm{H}_{20}{ }^{35} \mathrm{ClN}_{5} \mathrm{O}_{2} \mathrm{~S}_{2}+\mathrm{H}\right), 511(8)[\mathrm{M}+2]\left(\mathrm{C}_{24} \mathrm{H}_{20}{ }^{37} \mathrm{ClN}_{5} \mathrm{O}_{2} \mathrm{~S}_{2}\right), 329$ (100) $\left[\mathrm{M}+\mathrm{H}-\mathrm{C}_{8} \mathrm{H}_{10} \mathrm{~N}_{3} \mathrm{~S}-\mathrm{H}\right], 289$ (11) $\left[\mathrm{M}+\mathrm{H}-\mathrm{C}_{10} \mathrm{H}_{12} \mathrm{~N}_{3} \mathrm{OS}+\mathrm{H}\right]$, 222 (47) $\left[\mathrm{C}_{10} \mathrm{H}_{12} \mathrm{~N}_{3} \mathrm{OS}\right]^{+}, 204$ (13) [222-OH-H].

2-\{[(6-Bromo-4-oxo-3-phenyl-3,4-dihydroquinazolin2-yl)thio]acetyl\}-N-4-methoxyhydrazinecarbothioamide (2c): White bowder, m.p. $204^{\circ} \mathrm{C}$, yield (\%) $99^{\mathrm{A}} 76^{\mathrm{B}} 93^{\mathrm{C}}$, IR $\left(\mathrm{KBr}, \mathrm{v}_{\max }, \mathrm{cm}^{-1}\right): 3316,3243,3147(\mathrm{NH}), 1699\left(\mathrm{C}=\mathrm{O}_{\text {lactam }}\right)$, $1654\left(\mathrm{C}=\mathrm{O}_{\text {amide }}\right), 1469(\mathrm{C}=\mathrm{S}) ;{ }^{1} \mathrm{H}$ NMR $\left(\mathrm{DMSO}-d_{6}\right): 3.74(3 \mathrm{H}$, s, $\left.\mathrm{OCH}_{3}\right), 3.98\left(2 \mathrm{H}, \mathrm{s}, \mathrm{CH}_{2}-\mathrm{S}-\right), 6.87\left(2 \mathrm{H}, \mathrm{d},{ }^{3} \mathrm{~J}=8.8, \mathrm{H}-3\right.$ ", 5", $\mathrm{XX}^{\prime}$ part of AA'XX' system), $7.18\left(2 \mathrm{H}, \mathrm{d},{ }^{3} J=7.7, \mathrm{H}-2{ }^{\prime}, 6^{\prime}\right.$, AA' part of AA'XX' system), 7.48-7.61 (6H, m, H-8, 3', 4', 5', 2", 6"), 7.94 (1H, d, $\left.{ }^{3} J=8.8, \mathrm{H}-7\right), 8.14\left(1 \mathrm{H}, \mathrm{d},{ }^{4} \mathrm{~J}=1.8, \mathrm{H}-5\right)$, 9.38, 9.64, 10.29 (3H, br, s. NH groups); ${ }^{13} \mathrm{C}$ NMR: $35.1\left(\mathrm{CH}_{2}\right)$, $55.3\left(\mathrm{OCH}_{3}\right), 113.4,118.3,121.2(2 \mathrm{C}), 127.4,127.7,128.6$, 128.8, 129.4 (2C), 129.8 (2C), 130.3, 131.8 (2C), 135.6, 137.7,
$146.2,157.9\left(\mathrm{C}=\mathrm{O}_{\text {lactam }}\right), 159.7(\mathrm{C}-2), 166.9\left(\mathrm{C}=\mathrm{O}_{\text {amide }}\right), 181.1$ $(\mathrm{C}=\mathrm{S})\left(s p^{2}\right.$ carbons $) ; \mathrm{MS}: \mathrm{m} / \mathrm{z}(\%) 570(9)[\mathrm{M}+\mathrm{H}]^{+}$ $\left(\mathrm{C}_{24} \mathrm{H}_{20}{ }^{79} \mathrm{BrN}_{5} \mathrm{O}_{3} \mathrm{~S}_{2}+\mathrm{H}\right), 572(10)[\mathrm{M}+2]\left(\mathrm{C}_{24} \mathrm{H}_{20}{ }^{81} \mathrm{BrN}_{5} \mathrm{O}_{3} \mathrm{~S}_{2}+\mathrm{H}\right)$, 373 (99) $\left[\mathrm{M}+\mathrm{H}-\mathrm{C}_{8} \mathrm{H}_{10} \mathrm{~N}_{3} \mathrm{OS}-\mathrm{H}\right], 333$ (11) $[\mathrm{M}+\mathrm{H}-$ $\left.\mathrm{C}_{10} \mathrm{H}_{12} \mathrm{~N}_{3} \mathrm{O}_{2} \mathrm{~S}+\mathrm{H}\right], 238$ (100) $\left[\mathrm{C}_{10} \mathrm{H}_{12} \mathrm{~N}_{3} \mathrm{O}_{2} \mathrm{~S}\right]^{+}, 220$ (25) [238$\mathrm{OH}-\mathrm{H}]$.

6-Bromo-3-phenyl-2-\{[4-(4-methoxyphenyl)-5-thioxo-4,5dihydro-1H-1,2,4-triazol-3-yl)methyl]thio\}quinazolin4(3H)-one (3)

Method A for synthesis of (3): Synthesis was conducted according to the procedures in the literature ${ }^{35-37}$.

Method B for synthesis of (3): A solution of compound 2c (0.1 g, $0.0002 \mathrm{~mol})$ in a sodium hydroxide solution (4\%) was placed into a $25 \mathrm{~mL}$ conical flask, mixed and irradiated in the water bath of an ultrasonic cleaner at $80^{\circ} \mathrm{C}$ for $1.5 \mathrm{~h}$. The mixture was cooled, filtered and acidified with hydrochloric acid $(37 \%)$ to a $\mathrm{pH}$ of 5-7. The resulting solid was filtered, washed with water and recrystallized from ethanol. A yellowish white powder was obtained; m.p. $280^{\circ} \mathrm{C}$, yield (\%) $99^{\mathrm{A}} 22^{\mathrm{B}}$, IR (KBr, $\left.v_{\max }, \mathrm{cm}^{-1}\right): 3306(\mathrm{NH}), 1659(\mathrm{C}=\mathrm{O}), 1249(\mathrm{C}=\mathrm{S}) ;{ }^{1} \mathrm{H}$ NMR (CDCl $\mathrm{CDMSO}_{3}$ : $\left.d_{6}\right): 3.88\left(2 \mathrm{H}, \mathrm{s}, \mathrm{CH}_{2}-\mathrm{S}-\right), 3.90(3 \mathrm{H}, \mathrm{s}$, $\left.\mathrm{OCH}_{3}\right), 7.11\left(1 \mathrm{H}, \mathrm{d},{ }^{3} J=8.4, \mathrm{H}-8\right),\left(2 \mathrm{H}, \mathrm{d},{ }^{3} J=8.4, \mathrm{H}-3^{\prime}, 5^{\prime}\right.$, $\mathrm{XX}^{\prime}$ part of AA'XX' system), $7.27\left(2 \mathrm{H}, \mathrm{d},{ }^{3} J=7.5, \mathrm{H}-3 ", 5 "\right.$, $\mathrm{XX}^{\prime}$ part of $\mathrm{AA}^{\prime} \mathrm{XX}$ ' system), $7.36\left(1 \mathrm{H}, \mathrm{d},{ }^{3} J=8.4, \mathrm{H}-7\right), 7.45$ $\left(1 \mathrm{H}, \mathrm{t},{ }^{3} J=8.4, \mathrm{H}-4^{\prime}\right), 7.52\left(2 \mathrm{H}, \mathrm{d},{ }^{3} J=7.5, \mathrm{H}-2 ", 6^{\prime}, \mathrm{AA}^{\prime}\right.$ part of AA'XX' system), $7.69\left(2 \mathrm{H}, \mathrm{d},{ }^{3} J=8.4, \mathrm{H}-2\right.$ ', 6', AA' part of AA'XX' system), $8.12\left(1 \mathrm{H}, \mathrm{d},{ }^{4} J=1.8, \mathrm{H}-5\right), 10.87$ (1H, br, s, $\mathrm{NH}) ;{ }^{13} \mathrm{C}$ NMR spectral data of 3 were confirmed by $2 \mathrm{D}$ NMR ${ }^{1} \mathrm{H}-{ }^{13} \mathrm{C}-\mathrm{COSY}$ (HETCOR) and DEPT 135 experiments: 29.5 $\left(\mathrm{CH}_{2}\right), 55.5\left(\mathrm{OCH}_{3}\right), 115.2(\mathrm{C}-8), 117.6\left(2 \mathrm{C}-3^{\prime}, 5^{\prime}\right), 128.4(2 \mathrm{C}-$ 3", 5"), 128.6 (C-4'), 129.2 (2C-2", 6"), 130.0 (C-5), 130.2 (C-7), 137 (2C-2', 6'), $161.6\left(\mathrm{C}=\mathrm{O}_{\text {lactam }}\right), 165.4$ (C-2), $169.5(\mathrm{C}=\mathrm{S}), 116.1,134.9,138.8,140.8,147.4,150.5$, 160.4 ( $s p^{2}$ carbons). MS: m/z (\%) $552(39)[\mathrm{M}+\mathrm{H}]^{+}$ $\left(\mathrm{C}_{24} \mathrm{H}_{18}{ }^{79} \mathrm{BrN}_{5} \mathrm{O}_{2} \mathrm{~S}_{2}+\mathrm{H}\right), 553(8)[\mathrm{M}+2]\left(\mathrm{C}_{24} \mathrm{H}_{18}{ }^{81} \mathrm{BrN}_{5} \mathrm{O}_{2} \mathrm{~S}_{2}+\mathrm{H}\right)$, 521 (6) $\left[\mathrm{M}+\mathrm{H}-\mathrm{OCH}_{3}\right], 507$ (76) [M+H-CS-H], 463 (20) [M+H$\left.\mathrm{NC}_{6} \mathrm{H}_{5}+2 \mathrm{H}\right], 445(9)\left[\mathrm{M}+\mathrm{H}-\mathrm{OCH}_{3} \mathrm{C}_{6} \mathrm{H}_{4}\right]$.

Synthesis of potassium-2-(\{[6 or 7-substituted 3-(4-substituted phenyl)-4-oxo-3,4-dihydroquinaazolin-2-yl]thio\}acetyl)hydrazinecarbodithioate (4a-b): Synthesis was conducted according to the procedures in the literature ${ }^{38}$. Note that $\mathbf{4}$ was not detected in this reaction pathway.

2-\{[(4-Amino-5-thioxo-4,5-dihydro-1H-1,2,4-triazol-3yl)methyl]thio\} 6- or 7-substituted 3-(4-substituted phenyl)quinazolin-4(3H)-one (5a-b)

Method A for synthesis of (5a-b): A mixture of the potassium salt $\mathbf{4 a}$ or $\mathbf{4 b}(0.0002 \mathrm{~mol})$, hydrazine hydrate $99 \%$ $(0.3 \mathrm{~mL})$ and water $(1 \mathrm{~mL})$ was heated under reflux for $1 \mathrm{~h}$, diluted with ( $3 \mathrm{~mL})$ cold water, neutralized with hydrochloric acid $(37 \%)$ to a $\mathrm{pH}$ of 5-7 and then filtered. The solid was washed with water and purified by silica gel column chromatography (70-230 mesh) using chloroform/ethanol (9:1) as the eluent to yield the pure product (5a-b).

Method B for synthesis of (5a-b): A suspension of the potassium salt of $\mathbf{4 a}$ or $\mathbf{4 b}(0.0006 \mathrm{~mol})$, hydrazine hydrate $99 \%(0.3 \mathrm{~mL})$ and water $(9 \mathrm{~mL})$ in a $25 \mathrm{~mL}$ conical flask was mixed and irradiated in the water bath of an ultrasonic cleaner 
at $80{ }^{\circ} \mathrm{C}$ for $45 \mathrm{~min}$, diluted with $(3 \mathrm{~mL})$ cold water, neutralized with hydrochloric acid (37\%) to a $\mathrm{pH}$ of 5-7 and filtered. The solid was washed with water and recrystallized from ethanol (5b) or purified by column chromatography using chloroform/ ethanol (9:1) as the eluent $(\mathbf{5 a}-\mathbf{b})$.

2-\{[(4-Amino-5-thioxo-4,5-dihydro-1H-1,2,4-triazol-3yl)methyl]thio\}-7-chloro-3-(4-methoxyphenyl)quinazolin4(3H)-one (5a): White powder, m.p. $240{ }^{\circ} \mathrm{C}$, yield (\%) $56^{\mathrm{A}}$ $62^{\mathrm{B}}$, IR $\left(\mathrm{KBr}, v_{\max }, \mathrm{cm}^{-1}\right): 3349(\mathrm{NH}), 3301,3181\left(\mathrm{NH}_{2}\right), 1690$ $(\mathrm{C}=\mathrm{O}), 1461(\mathrm{C}=\mathrm{S}) ;{ }^{1} \mathrm{H}$ NMR $\left(\mathrm{DMSO}-d_{6}\right): 3.84\left(1 \mathrm{H}, \mathrm{s}, \mathrm{OCH}_{3}\right)$, $3.97\left(1 \mathrm{H}, \mathrm{s}, \mathrm{CH}_{2}\right), 4.31\left(2 \mathrm{H}, \mathrm{br}, \mathrm{s}, \mathrm{NH}_{2}\right), 7.11\left(2 \mathrm{H}, \mathrm{d},{ }^{3} J=8.8\right.$, H-3',5', XX' part of AA'XX' system), 7. $38\left(2 \mathrm{H}, \mathrm{d},{ }^{3} \mathrm{~J}=8.8, \mathrm{H}-\right.$ 2', 6', AA' part of AA'XX' system), 7.47-7.61 (2H, m, H-5, 8), $8.06\left(1 \mathrm{H}, \mathrm{dd},{ }^{3} J=8.4,{ }^{4} J=2.6, \mathrm{H}-6\right), 10.31(1 \mathrm{H}, \mathrm{br}, \mathrm{s}, \mathrm{NH})$; ${ }^{13} \mathrm{C}$ NMR: $34.6\left(\mathrm{CH}_{2}\right), 54.7\left(\mathrm{OCH}_{3}\right), 113.9(2 \mathrm{C}), 117.6,124.2$, 125.2, 125.3, 128.0, 129.7 (2C), 138.5, 147.3, 150.5, 155.6, $159.5,\left(\mathrm{C}=\mathrm{O}_{\text {lactam }}\right), 162.4(\mathrm{C}-2), 167.8(\mathrm{C}=\mathrm{S})\left(s p^{2}\right.$ carbons $)$.

2-\{[(4-Amino-5-thioxo-4,5-dihydro-1H-1,2,4-triazol-3yl)methyl]thio -6-bromo-3-(4-methylphenylphenyl) quinazolin-4(3H)-one (5b): Pale gray powder, m.p. $195^{\circ} \mathrm{C}$, (from ethanol); yield (\%) 50 $0^{\mathrm{A}}, 59^{\mathrm{B}}, \mathrm{IR}\left(\mathrm{KBr}, \nu_{\max }, \mathrm{cm}^{-1}\right): 3349$ $(\mathrm{NH}), 3301,3181\left(\mathrm{NH}_{2}\right), 1690(\mathrm{C}=\mathrm{O}), 1461(\mathrm{C}=\mathrm{S}) ;{ }^{1} \mathrm{H}$ NMR $\left(\mathrm{CDCl}_{3}: \mathrm{DMSO}-d_{6}\right): 2.46\left(1 \mathrm{H}, \mathrm{s}, \mathrm{CH}_{3}\right), 3.82\left(1 \mathrm{H}, \mathrm{s}, \mathrm{CH}_{2}\right), 4.09$ $\left(2 \mathrm{H}, \mathrm{br}, \mathrm{s}, \mathrm{NH}_{2}\right), 7.23\left(2 \mathrm{H}, \mathrm{d},{ }^{3} \mathrm{~J}=8.1, \mathrm{H}-3^{\prime}, 5^{\prime}, \mathrm{XX}^{\prime}\right.$ part of AA'XX' system), $7.36\left(2 \mathrm{H}, \mathrm{d},{ }^{3} J=8.1, \mathrm{H}-2^{\prime}, 6^{\prime}, \mathrm{AA}^{\prime}\right.$ part of AA'XX' system), $7.56\left(1 \mathrm{H}, \mathrm{d},{ }^{3} J=9, \mathrm{H}-8\right), 7.83\left(1 \mathrm{H}, \mathrm{dd},{ }^{3} J=\right.$ $\left.9,{ }^{4} \mathrm{~J}=2.4, \mathrm{H}-7\right), 8.24\left(1 \mathrm{H}, \mathrm{d},{ }^{4} J=2.4, \mathrm{H}-5\right), 9.81(1 \mathrm{H}, \mathrm{br}, \mathrm{s}$, $\mathrm{NH}) ;{ }^{13} \mathrm{C}$ NMR spectral data of $\mathbf{5 b}$ were confirmed by $2 \mathrm{D}$ NMR ${ }^{1} \mathrm{H}^{13} \mathrm{C}-\mathrm{COSY}$ (HETCOR) and DEPT 135 experiments: 21.2 $\left(\mathrm{CH}_{3}\right), 34.4\left(\mathrm{CH}_{2}\right), 128.2(\mathrm{C}-8), 128.7$ (2C-3', 5'), $129.1(\mathrm{C}-5)$, 130.2 (2C-2', 6'), 137.5 (C-7), $157.7\left(\mathrm{C}=\mathrm{O}_{\text {lactam }}\right), 160.1$ (C-2), $167.4(\mathrm{C}=\mathrm{S}), 118.6,121.1,132,5,140.2,146.2$ [one carbon with the baseline] ( $s p^{2}$ carbons).

2-[(6 or 7-Substituted (4-substituted phenyl)-4-oxo-3,4dihydrequinazolin-2-yl)thio]-N'-(3,4 substituted benzylidene)acetohydrazide (6a-d)

Method A for synthesis of (6a-c): Equimolar quantities of hydrazide $\mathbf{1 b}$ or $\mathbf{1 e}$ or $\mathbf{1 f}$ and the substities aldehydes $(0.0002$ $\mathrm{mol}$ ) were refluxed in absolute ethanol for $2 \mathrm{~h}$ (TLC), the reactions were filtered and the products were dried and recrystallized from benzene.

Method B for synthesis of (6a,c-d): A solution of the hydrazides $\mathbf{1 b}, \mathbf{1 e}$ or $\mathbf{1 g}$ and the substituted aldehyde $(0.0002$ $\mathrm{mol}$ ) in absolute ethanol was irradiated in the water bath of an ultrasonic cleaner for 15-45 $\min$ (TLC). The reactions were filtered and the products were dried and recrystallized from benzene.

Method C for synthesis of (6c-d): A few drops of absolute ethanol were added to an equimolar amount of hydrazide $1 \mathrm{e}$ or $\mathbf{1 g}$ and the substituted aldehyde $(0.0002 \mathrm{~mol})$. This solution was irradiated in a microwave for 5-15 min (TLC). The solid product was treated with ethanol, filtered, dried and recrystallized from benzene.

2-[(7-Chloro-3-phenyl-4-oxo-3,4-dihydroquinazolin-2yl)thio]-N'-(3,4-dimethoxybenzylidene)acetohydrazide (6a): Beige scales, m.p. $269^{\circ} \mathrm{C}$, yield (\%) 83 $3^{\mathrm{A}}, 36^{\mathrm{B}}$, IR (KBr, $\left.V_{\max }, \mathrm{cm}^{-1}\right): 3167(\mathrm{NH}), 1678\left(\mathrm{C}=\mathrm{O}_{\text {lactam }}\right), 1656\left(\mathrm{C}=\mathrm{O}_{\text {amide }}\right)$; $\mathrm{MS}$ : $\mathrm{m} / \mathrm{z}(\%) 509(7)[\mathrm{M}+\mathrm{H}]^{+}\left(\mathrm{C}_{25} \mathrm{H}_{21}{ }^{35} \mathrm{ClN}_{4} \mathrm{O}_{4} \mathrm{~S}+\mathrm{H}\right), 510(3)[\mathrm{M}+2]$
$\left(\mathrm{C}_{25} \mathrm{H}_{21}{ }^{37} \mathrm{ClN}_{4} \mathrm{O}_{4} \mathrm{~S}\right), 329$ (100) [M+H-C $\left.{ }_{9} \mathrm{H}_{11} \mathrm{~N}_{2} \mathrm{O}_{2}-\mathrm{H}\right], 301$ (5)

[329-CO], 180 (4) [M+H- $\left.\mathrm{C}_{16} \mathrm{H}_{10}{ }^{35} \mathrm{ClN}_{2} \mathrm{O}_{2} \mathrm{~S}+\mathrm{H}\right]$.

2-[(7-Chloro-3-phenyl-4-oxo-3,4-dihydroquinazolin-2yl)thio]-N'-(4-nitrobenzylidene)acetohydraazide (6b): Yellowish white fine needles, m.p. $240{ }^{\circ} \mathrm{C}$, yield (\%) $77^{\mathrm{A}}$, IR $\left(\mathrm{KBr}, v_{\max }, \mathrm{cm}^{-1}\right): 3126(\mathrm{NH}), 1689\left(\mathrm{C}=\mathrm{O}_{\text {lactam }}\right), 1666\left(\mathrm{C}=\mathrm{O}_{\text {amide }}\right)$; ${ }^{1} \mathrm{H} \mathrm{NMR}\left(\mathrm{CDCl}_{3}: \mathrm{DMSO}-d_{6}\right): 448\left(1 \mathrm{H}, \mathrm{s}, \mathrm{CH}_{2}\right), 7.38-7.47(3 \mathrm{H}$, m, H-3', 4', 5'), 7.47 (1H, d, $\left.{ }^{4} J=1.8, \mathrm{H}-8\right), 7.59-7.60$ (3H, m, H-6, 2', 6'), $7.92\left(2 \mathrm{H}, \mathrm{d},{ }^{3} J=8.4, \mathrm{H}-2^{\prime}, 6^{\prime}, \mathrm{XX}^{\prime}\right.$ part of AA'XX' system), 8.08 (2H, d, $\left.{ }^{3} J=8.4, \mathrm{H}-5\right), 8.16(1 \mathrm{H}, \mathrm{s},=\mathrm{CH}), 8.25$ $\left(2 \mathrm{H}, \mathrm{d},{ }^{3} J=8.4, \mathrm{H}-3^{\prime}, 5^{\prime \prime}, \mathrm{XX}^{\prime}\right.$ part of AA'XX' system), 11.93 $(1 \mathrm{H}, \mathrm{br}, \mathrm{s}, \mathrm{NH}) ;{ }^{13} \mathrm{C}$ NMR spectral data of $\mathbf{6 b}$ were confirmed by $2 \mathrm{D}-\mathrm{NMR}{ }^{1} \mathrm{H}-{ }^{13} \mathrm{C}-\mathrm{COSY}$ (HETCOR) and DEPT 135 experiments: $34.1\left(\mathrm{CH}_{2}\right), 123.2$ (2C-3", 5"), 125.1 (C-8), 125.8 (C-4'), 127.3 (2C-2",6"), 128.2 (C-5), 128.8 (2C-3', 5'), 129.3 (2C-2', 6'), 129.7 (C-6), 160.1 (C=O lactam $), 164.1$ (C-2), 168.9 $\left(\mathrm{C}=\mathrm{O}_{\text {amide }}\right), 117.9,135.1,140.1,145.5,147.9,158.3\left(s p^{2}\right.$ carbons); MS: $\mathrm{m} / \mathrm{z}(\%) 494(4)[\mathrm{M}+\mathrm{H}]^{+}\left(\mathrm{C}_{23} \mathrm{H}_{16}{ }^{35} \mathrm{ClN}_{5} \mathrm{O}_{4} \mathrm{~S}+\mathrm{H}\right)$, $495(2)[\mathrm{M}+2]\left(\mathrm{C}_{23} \mathrm{H}_{16}{ }^{37} \mathrm{ClN}_{5} \mathrm{O}_{4} \mathrm{~S}\right), 329(100)\left[\mathrm{M}+\mathrm{H}-\mathrm{C}_{7} \mathrm{H}_{6} \mathrm{~N}_{3} \mathrm{O}_{2^{-}}\right.$ $\mathrm{H}$ ], 301 (10) [329-CO], 128 (3\%) [301-Ph-N=C=O], 166 (4) $\left[\mathrm{M}+\mathrm{H}-\mathrm{C}_{16} \mathrm{H}_{10}{ }^{35} \mathrm{ClN}_{2} \mathrm{O}_{2} \mathrm{~S}+\mathrm{H}\right]$.

N'-(4-Bromobenzylidene)-2-[(6-bromo-3-phenyl-4oxo-3,4-dihydroquinazolin-2-yl) thio]acetohydrazide (6c): White scales, m.p. $257^{\circ} \mathrm{C}$, yield (\%) $99^{\mathrm{A}}, 75^{\mathrm{B}}, 99^{\mathrm{C}}$, IR $(\mathrm{KBr}$, $\left.V_{\max }, \mathrm{cm}^{-1}\right): 3180(\mathrm{NH}), 1696\left(\mathrm{C}=\mathrm{O}_{\text {lactam }}\right), 1673\left(\mathrm{C}=\mathrm{O}_{\text {amide }}\right)$; MS: $\mathrm{m} / \mathrm{z} 571(7)[\mathrm{M}+\mathrm{H}]^{+}\left(\mathrm{C}_{23} \mathrm{H}_{16}{ }^{79} \mathrm{Br}_{2} \mathrm{~N}_{4} \mathrm{O}_{2} \mathrm{~S}+\mathrm{H}\right), 573(16)[\mathrm{M}+2]$ $\left(\mathrm{C}_{23} \mathrm{H}_{16}{ }^{79,81} \mathrm{Br}_{2} \mathrm{~N}_{4} \mathrm{O}_{2} \mathrm{~S}+\mathrm{H}\right), 575(7)[\mathrm{M}+4]\left(\mathrm{C}_{23} \mathrm{H}_{16}{ }^{81} \mathrm{BrN}_{4} \mathrm{O}_{2} \mathrm{~S}+\mathrm{H}\right)$, 373 (100) $\left[\mathrm{M}+\mathrm{H}-\mathrm{C}_{7} \mathrm{H}_{6}{ }^{79} \mathrm{BrN}_{2}\right.$ ], 345 (15) [373-CO], 210 (13) $\left[\mathrm{M}+\mathrm{H}-\mathrm{C}_{9} \mathrm{H}_{8}{ }^{79} \mathrm{BrN}_{2} \mathrm{O}-\mathrm{Ph}-\mathrm{N}=\mathrm{C}=\mathrm{O}-2 \mathrm{H}\right]$.

2-[(6-Iodo-(4-methoxyphenyl)-4-oxo-3,4-dihydroquinazolin-2-yl)thio]-N'-(4-nitrobenzylidene)acetohydrazide (6d): White scales, m.p. $264{ }^{\circ} \mathrm{C}$, yield (\%) 84 ${ }^{\mathrm{A}}$, $71^{\mathrm{B}}, 99^{\mathrm{C}}, \mathrm{IR}\left(\mathrm{KBr}, v_{\max }, \mathrm{cm}^{-1}\right): 3178(\mathrm{NH}), 1680\left(\mathrm{C}=\mathrm{O}_{\text {lactam }}\right), 1680$ $\left(\mathrm{C}=\mathrm{O}_{\text {amide }}\right) ; \mathrm{MS}: \mathrm{m} / \mathrm{z}(\%) 616(24)[\mathrm{M}+\mathrm{H}]^{+}\left(\mathrm{C}_{24} \mathrm{H}_{18} \mathrm{IN}_{5} \mathrm{O}_{5} \mathrm{~S}+\mathrm{H}\right)$, 451 (100) $\left[\mathrm{M}+\mathrm{H}-\mathrm{C}_{7} \mathrm{H}_{6} \mathrm{~N}_{3} \mathrm{O}_{2}-\mathrm{H}\right], 423$ (2) [451-CO].

Antibacterial activity: The in vitro antibacterial activity of some compounds was determined using the cup-plate diffusion method ${ }^{39}$. The nearest zone of inhibition was measured in $\mathrm{mm}$. The concentration $(100 \mu \mathrm{g} / \mathrm{mL})$ of the test compounds was adjusted by dissolving the compounds in dimethyl sulfoxide. The antibiotic gentamycin was used as a standard $(100 \mu \mathrm{g} / \mathrm{mL})$ antibacterial agent. The antibacterial activity was screened against two gram-negative bacteria (Escherichia coli ATCC25922 and Pseudomonas aeruginosa ATCC27853) and two grampositive bacteria (Bacillus subtilis ATCC6633 and Staphylococcus aureus ATCC25923), the bacterial cultures were adjusted to 0.5 McFarland turbidity standard.

\section{RESULTS AND DISCUSSION}

The condensation of the hydrazide derivative $\mathbf{1 a}, \mathbf{b}, \mathbf{e}$ with aryl isothiocyanate derivatives resulted in the formation of 2a-c. Different methods were used to prepare 2a-c, in good yield, including the traditional methods, microwave and ultrasound irradiation methodologies. The structures of 2a-c were assigned on the basis of the spectroscopic analyses. The IR spectrum of compound 2a exhibited bands at 3317, 3278 and $3180 \mathrm{~cm}^{-1}$ due to $\mathrm{NH}$ stretching and the lactam $\mathrm{C}=\mathrm{O}$ stretching of the quinazolinone ring and amide $\mathrm{C}=\mathrm{O}$ stretching 
were observed at 1686 and $1659 \mathrm{~cm}^{-1}$, respectively. The ${ }^{1} \mathrm{H}$ NMR spectrum of $\mathbf{2 a}$ exhibited a singlet at $\delta 2.42 \mathrm{ppm}$, which corresponded to the methyl protons and a singlet at $\delta 4.01$ ppm, which corresponded to the methylene group. A triplet signal was also observed at $\delta 7.15 \mathrm{ppm}(J=7.4 \mathrm{~Hz})$, which was assigned to H-4'. This spectrum also displayed a multiplet signal at $\delta 7.29-7.41 \mathrm{ppm}$, which integrated to eight protons and was assigned to protons C-2', 3', 5', 6', 2", 3", 5" and 6-H, whereas the doublet signal at $\delta 7.47 \mathrm{ppm}(J=8.1 \mathrm{~Hz})$ was assigned to $\mathrm{H}-6$. Two doublet signals were observed at $\delta 7.65$ ppm and $\delta 8.08 \mathrm{ppm}(J=8.1 \mathrm{~Hz})$, which were assigned to the protons at positions 8 and 5, respectively (Scheme-I) and the doublet signal at $\delta 7.80 \mathrm{ppm}(J=8.1 \mathrm{~Hz})$ was assigned to $\mathrm{H}-7$. Furthermore, the presence of singlet signals at $\delta 9.53$, 9.74 and $10.34 \mathrm{ppm}$, which are exchangeable with $\mathrm{D}_{2} \mathrm{O}$, were assigned to the $\mathrm{NH}$ groups. The ${ }^{13} \mathrm{C}$ NMR spectrum of $2 \mathbf{a}$ displayed signals at $\delta 20.9 \mathrm{ppm}$ for the methyl carbon, 35.0 $\mathrm{ppm}$ for the methylene group carbon, $126.2 \mathrm{ppm}$ for C-6, 126.3 ppm for C-8, $126.6 \mathrm{ppm}$ for C-5, $134.9 \mathrm{ppm}$ for C-7, 128.3 ppm for C-4", $157.1 \mathrm{ppm}$ for (C=O lactam), $160.8 \mathrm{ppm}$ for $\mathrm{C}-2,166.9 \mathrm{ppm}$ for $(\mathrm{C}=\mathrm{O}$ amide $), 180.7 \mathrm{ppm}$ for $(\mathrm{C}=\mathrm{S})$ and 9 lines at $\delta 119.5,133.1,138.9,139.8,147.1,126.1(2 \mathrm{C}), 129.1$ (2C), 129.2 (2C), 130.1 (2C) for other aromatic carbons. The assignment of all protons and carbons in $\mathbf{2 a}$ were verified by the analysis with DEPT and ${ }^{1} \mathrm{H}-{ }^{13} \mathrm{C}$ Cosy techniques. The mass spectrum of 2a exhibited a molecular ion peak $[\mathrm{M}+\mathrm{H}]^{+}$at $\mathrm{m} / \mathrm{z} 476$ which is in agreement with its assigned structure.

Compound $\mathbf{2 c}$ was used in the cyclization reaction with sodium hydroxide under reflux and produced the triazolthione 3, which was also obtained following ultrasound irradiation under the same conditions in moderate yield. The IR spectrum of $\mathbf{3}$ exhibited an absorption band at $3306 \mathrm{~cm}^{-1}$ for $\mathrm{NH}$ group, the strong absorption at $1659 \mathrm{~cm}^{-1}$ is due to the $(\mathrm{C}=\mathrm{O}$ lactam $)$ stretching vibration and the absorption with strong intensity at $1249 \mathrm{~cm}^{-1}$ corresponds to a $\mathrm{C}=\mathrm{S}$ stretching vibration.

The ${ }^{1} \mathrm{H}$ NMR spectrum of $\mathbf{3}$ revealed two singlet signals in the aliphatic region at $\delta 3.88$ and $\delta 3.90$, which were integrated for 2 and 3 protons, respectively and attributed to the $\mathrm{CH}_{2}$ and $\mathrm{OCH}_{3}$ groups. All other aromatic protons in this spectrum appeared at their expected chemical shifts. The ${ }^{13} \mathrm{C}$ NMR data of $\mathbf{3}$ were fully consistent with its structure. The ${ }^{13} \mathrm{C}$ chemical shift values of some carbons assigned by the $2 \mathrm{D}$ NMR ${ }^{1} \mathrm{H}_{-}{ }^{13} \mathrm{C}-\mathrm{COSY}(\mathrm{HETCOR})$ and DEPT 135 data are shown in Fig. 1. The mass spectrum of 3 revealed $[\mathrm{M}+\mathrm{H}]^{+}$at $\mathrm{m} / \mathrm{z} 552$ and at $\mathrm{m} / \mathrm{z} 553$ with almost equal intensity, as expected for bromine isotopes.

The cyclisation of the potassium salts of $\mathbf{4 a - b}$ with $99 \%$ hydrazine hydrate, either using the conventional method or by ultrasoincation, under the conditions stated in (Scheme-I) produced the S-triazoles 5a-b in good-moderate yields. The IR spectrum of compound $\mathbf{5 b}$ exhibited absorption bands at 3241,3263 and $3202 \mathrm{~cm}^{-1}$, which were assignable to $\mathrm{NH} / \mathrm{NH}_{2}$, in addition to the presence of a strong absorption band at 1670 $\mathrm{cm}^{-1}$ due to a carbonyl group and $\mathrm{C}=\mathrm{S}$ stretching frequencies at $1466 \mathrm{~cm}^{-1}$. The ${ }^{1} \mathrm{H}$ NMR in (DMSO- $d_{6}: \mathrm{CDCl}_{3}$ ) displayed 3 singlet signals at $\delta 2.46,3.82$ and 9.18 ppm which are characteristic of a methyl group, methylene protons and a $\mathrm{NH}$ proton, respectively. Although the signal from the $\mathrm{NH}_{2}$ group appeared weak, the aromatic protons appeared as a pair of doublets at

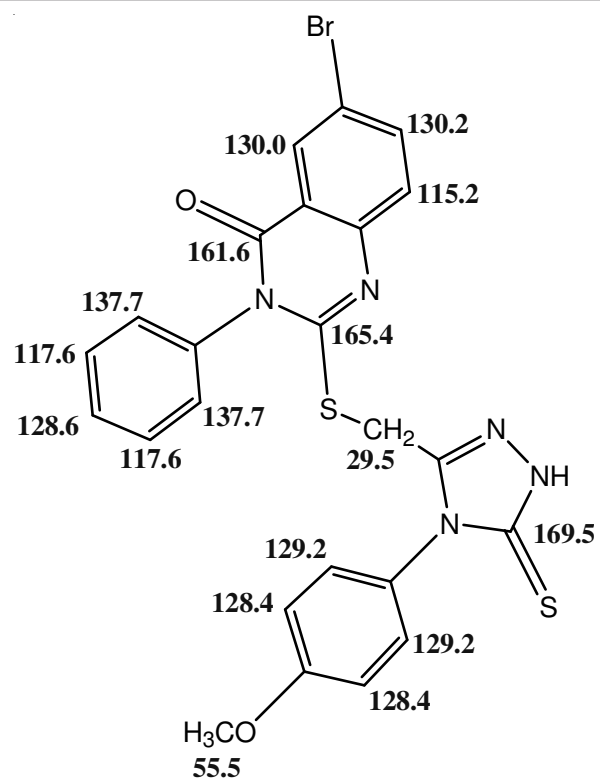

Fig. 1. Structure and ${ }^{13} \mathrm{C}$ NMR data of some carbon atoms in $\mathbf{3}$

$\delta 7.23 \mathrm{ppm}\left(\mathrm{H}-3^{\prime}, 5^{\prime}\right)$ and $\delta 7.36 \mathrm{ppm}\left(\mathrm{H}-2^{\prime}, 6^{\prime}\right)$ with $J=8.1 \mathrm{~Hz}$ and the other aromatic protons in this spectrum appeared at their expected chemical shifts. Further, the ${ }^{13} \mathrm{C}$ NMR data of $\mathbf{5 b}$ is fully consistent with its assigned structure (Fig. 2).

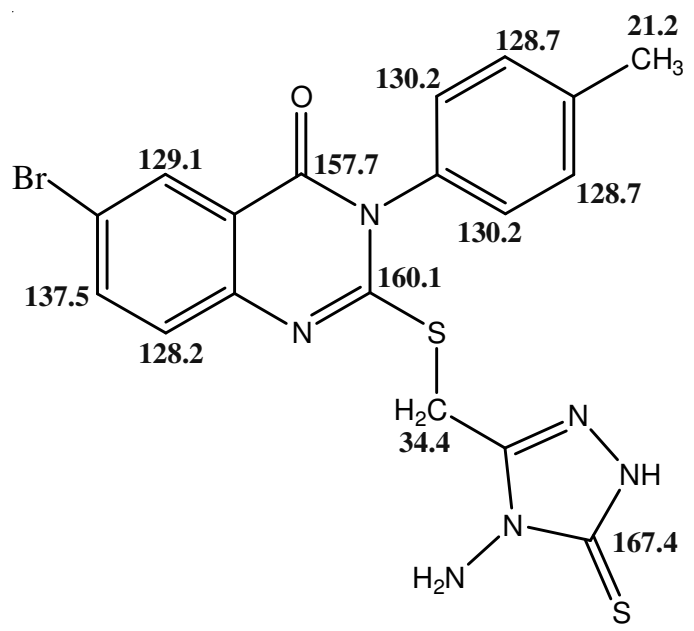

Fig. 2. ${ }^{13} \mathrm{C}$ chemical shift values some of carbons are assigned by ${ }^{1} \mathrm{H}-{ }^{13} \mathrm{C}-$ COSY and DEPT 135 data of $\mathbf{5 b}$

The hydazide derivatives $\mathbf{1 b}$,e-f easily condensed with aromatic aldehydes such as 4-bromo benzaldehyde, 3,4 dimethoxyl benzaldehyde and 4-nitro benzaldehyde under different reactions conditions, e.g., microwave irradiation, ultrasonication and classical heating, to produce 6a-d in excellent yields. The IR spectrum of $\mathbf{6 b}$ exhibited absorption band at $3126 \mathrm{~cm}^{-1}$ for the NH group, a band at $1689 \mathrm{~cm}^{-1}$ due to $\mathrm{C}=\mathrm{O}_{\text {(lactam) }}$ and a band in the $1666 \mathrm{~cm}^{-1}$ region from $\mathrm{C}=\mathrm{O}$ (amide) stretching. The chemical shifts of all the protons absorptions in the ${ }^{1} \mathrm{H}$ NMR spectrum of $\mathbf{6 b}$ and the carbon signals in the ${ }^{13} \mathrm{C}$ NMR spectrum were fully consistent with its structure. The mass spectrum of compound $\mathbf{6 b}$ revealed a molecular ion peak at $\mathrm{m} / \mathrm{z}=494\left([\mathrm{M}+\mathrm{H}]^{+}, 18 \%\right)$ and a base peak was observed in the spectrum at $\mathrm{m} / \mathrm{z}=329$ $(100 \%)$, which is compatible with its molecular formula of $\mathrm{C}_{23} \mathrm{H}_{16}{ }^{35} \mathrm{ClN}_{5} \mathrm{O}_{4}+\mathrm{H}$. 

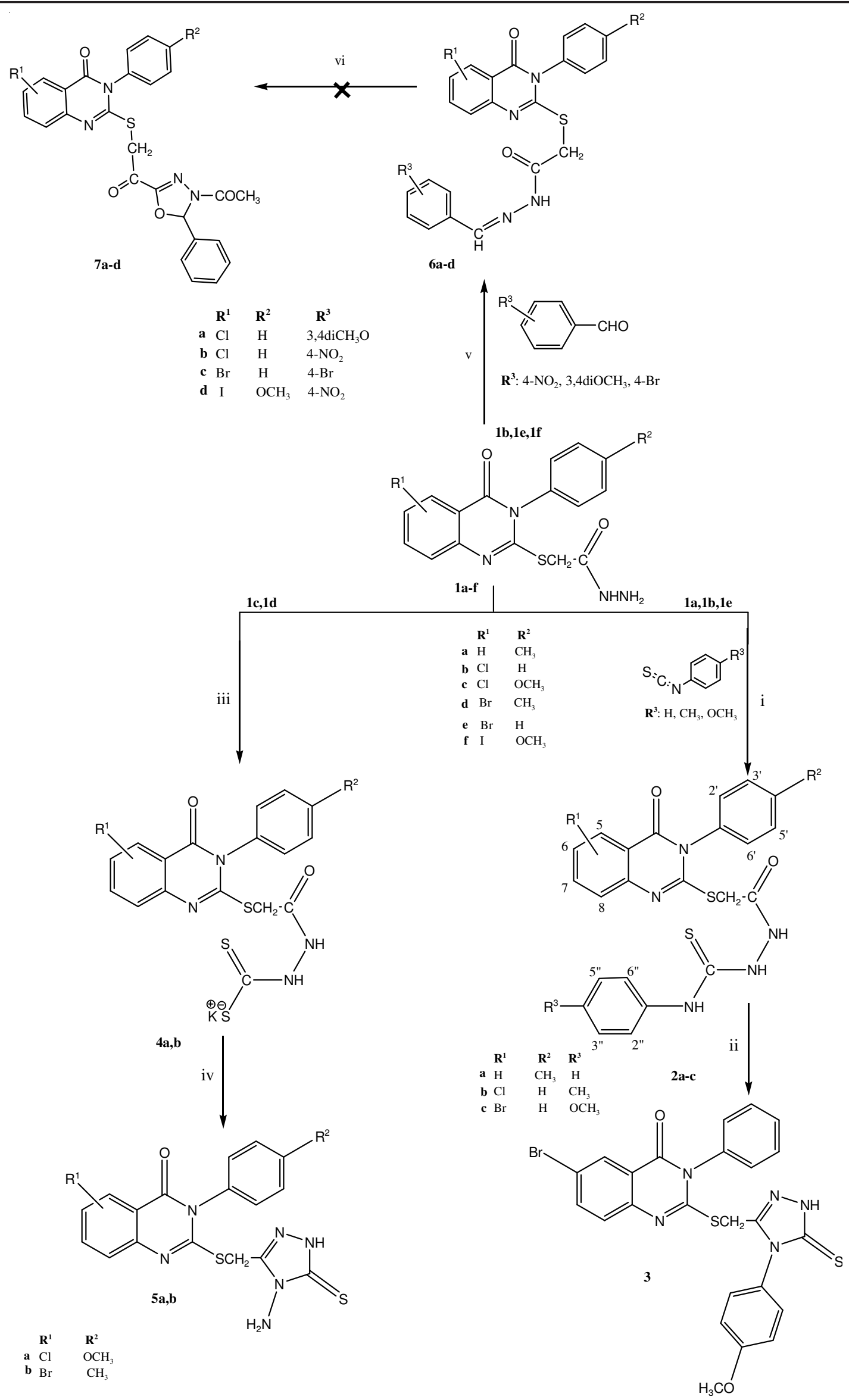

Scheme-I: (i) A: Absolute EtOH, reflux, 1 h (2a-c); B: US, 15 min (2a-c); C: MW, 5 min (2a,c). (ii) A: $\mathrm{NaOH}(4 \%), \mathrm{HCl}$ (37 \%), reflux, 3 h; B: US, 1.5 h. (iii) $\mathrm{KOH} /$ absolute EtOH, $\mathrm{CS}_{2}$, dry. ether, stirring, 14 h. (iv) A: $\mathrm{H}_{2} \mathrm{O}, \mathrm{N}_{2} \mathrm{H}_{4} \cdot \mathrm{H}_{2} \mathrm{O} 99 \%, \mathrm{HCl}(37 \%$ ), reflux, 1 h; B: US, 45 min. (v) A: absolute EtOH, reflux, 2 h (6a-d); B: US, 15-45 min (6a,c-d); C: MW, 5-15 min (6c-d). (vi) A: acetaic anhydride, reflux, 1-6 h (7a-d); B: US, 2 h; C: MW, 1 h 
Mallikarjuna et $a l .{ }^{40}$ reported that refluxing a mixture of hydrazones 6a-d and acetic anhydride afforded the oxadiazole 7a-d, also we used microwave and ultrasonic irradiation methods, but when performing the same reaction we did not isolate 7a-d.

Antibacterial activity: The results of the antibacterial activity are shown in (Table-1). Compounds $\mathbf{2 a}, \mathbf{2 b}, \mathbf{2 c}$ and $\mathbf{5 b}$ exhibited good activities against gram-positive bacterial $S$. aureus whereas compounds $\mathbf{3}$ and $\mathbf{5 a}$ displayed good activity against the gram-negative bacterial $P$. aeruginosa. Compound 6b also exhibited good activity against the gram-positive bacterial $B$. asubtilis whereas all compounds showed good to moderate activity against the gram-negative bacterial $E$. coli. All of the compounds possessed moderate to poor activities compared to gentamycin.

\begin{tabular}{ccccc} 
& \multicolumn{4}{c}{ TABLE-1 } \\
& $\begin{array}{c}\text { ANTIBACTERIAL ACTIVITY AT A } \\
\text { CONCENTRATION OF 100 } \mu \mathrm{g} / \mathrm{mL}\end{array}$ \\
\hline Test & \multicolumn{3}{c}{ Zone of inhibition in diameter (mm) } \\
\cline { 2 - 5 } organisms \\
\cline { 2 - 5 } compound & \multicolumn{2}{c}{ Gram-negative } & \multicolumn{2}{c}{ Gram-positive } \\
\cline { 2 - 5 } & E. coli & P. aeruginosa & S. aureus & B. asubtilis \\
\hline $\mathbf{2 a}$ & 11 & 14 & 15 & 9 \\
$\mathbf{2 b}$ & 14 & 13 & 17 & 10 \\
$\mathbf{2 c}$ & 14 & 11 & 15 & 11 \\
$\mathbf{3}$ & 13 & 16 & 0 & 12 \\
$\mathbf{5 a}$ & 11 & 16 & 12 & 9 \\
$\mathbf{5 b}$ & 11 & 9 & 15 & 9 \\
$\mathbf{6 b}$ & 13 & 0 & 10 & 15 \\
Gentamycin & 23 & 36 & 27 & 34 \\
\hline
\end{tabular}

$*$ Diameter of well (bore size) $=5 \mathrm{~mm}$.

\section{Conclusion}

The syntheses of some new thioxoquinazolin-4(3H)-one derivatives using microwave, ultrasonic and classical heating have been described. The structures of compounds 2-6 were confirmed through spectral data (IR, ${ }^{1} \mathrm{H}$ NMR, ${ }^{13} \mathrm{C}$ NMR, 2D NMR and ESI-MS). The results indicated that the compounds exhibited good to poor antibacterial activity.

\section{ACKNOWLEDGEMENTS}

This project was supported by King Saud University, Deanship of Scientific, College of Science Research Center.

\section{REFERENCES}

1. G.P. Sureaha, R. Suhas, W. Kapfo and D.C. Gowda, Eur. J. Med. Chem., 46, 2530 (2011).

2. A. Kumar, P. Sharma, P. Kumari and B. Lal-Kalal, Bioorg. Med. Chem. Lett., 21, 4353 (2011).

3. A.M. Alafeefy, A.S. El-Azab, M.A. Mohamed, M.A. Bakhat and S.G. Abdel-Hamid, J. Saudi Chem. Soc., 15, 319 (2011).

4. N.B. Patel and J.C. Patel, Arabian J. Chem., 4, 403 (2011).

5. D.R. Patel and K.C. Patel, Dyes Pigm., 90, 1 (2011).

6. K.S. Prasad, L.S. Kumar, S. Chandan and B. Jayalakshmi, Spectrochim. Acta A, 81, 276 (2011).

7. V.G. Ugale, H.M. Patel, S.G. Wadodkar, S.B. Bari and A.A. Skirkhedkar, Eur. J. Med. Chem., 53, 107 (2011).

8. A.S. El-Azab and K.E.H. El-Tahir, Bioorg. Med. Chem. Lett., 22, 327 (2012).

9. A.S. El-Azab and K.E.H. El-Tahir, Bioorg. Med. Chem. Lett., 22, 1879 (2012).
10. M.M. Aly, Y.A. Mohamed, K.A.M. EL-Bayouki, W.M. Basyouni and S.Y. Abbas, Eur. J. Med. Chem., 45, 3365 (2010).

11. A. Kamal, E.V. Bharathi, M.J. Ramaiah, D. Dastagiri, J.S. Reddy, A. Viswanath, F. Sultana, S.N.C.V.L. Pushpavalli, M. Pal-Bhadra, H.K. Srivastava, G.N. Sastry, A. Juvekar, S. Sen and S. Zingde, Bioorg. Med. Chem., 18, 526 (2010).

12. A.M. Al-Obaid, S.G. Abdel-Hamide, H.A. El-Kashef, A.A.-M. AbdelAziz, A.S. El-Azab, H.A. Al-Khamees, H.I. El-Subbagh, Eur. J. Med. Chem., 44, 2379 (2009).

13. A.S. El-Azab, M.A. Al-Omar, A.A.-M. Abdel-Aziz, N.I. Abdel-Aziz, M.A.-A. El-Sayed, A.M. Aleisa, M.M. Sayed-Ahmed and S.G. AbdelHamide, Eur. J. Med. Chem., 45, 4188 (2010).

14. A. Mrozek-Wilczkiewicz, D.S. Kalinowski, R. Musiol, J. Finster, A. Szurko, K. Serafin, M. Knas, S.K. Kamalapuram, Z. Kovacevic, J. Jampilek, A. Ratuszna, J. Rzeszowska-Wolny, D. Richardson and J. Polanski, Bioorg. Med. Chem., 18, 2664 (2010).

15. H.-Y. Li, Y. Wang, W.T. McMillen, A. Chatterjee, J.E. Toth, S.R. Mundla, M. Voss, R.D. Boyer and J.S. Sawyer, Tetrahedron, 63, 11763 (2007).

16. S.-L. Cao, Y.-Pi. Feng, Y.-Y. Jiang, S.-Y. Liu, G.-Y. Ding and R.-T. Li, Bioorg. Med. Chem. Lett., 15, 1915 (2005).

17. C. Ye, J. You, X. Li, R. You, Y. Weng, J. Li and Y. Wang, Pestic. Biochem. Physiol., 97, 197 (2010).

18. Y.H. Na, S.H. Hong, J.H. Lee, W.K. Park, D.J, Baek, H.Y. Koh, Y.S. Cho, H. Choo and A.N. Paea, Bioorg. Med. Chem., 16, 2570 (2008).

19. V. Alagarsamy, D. Shankar and S. Murugesan, Biomed. Pharmacother., 62, 173 (2008)

20. T. Mizutani, T. Nagase, S. Ito, Y. Miyamoto, T. Tanaka, N. Takenaga, S. Tokita and N. Sato, Bioorg. Med. Chem. Lett., 18, 6041 (2008).

21. K.M. Amin, M.M. Kamel, M.M. Anwar, M. Khedr and Y.M. Syam, Eur. J. Med. Chem., 45, 2117 (2010).

22. R.S. Giri, H.M. Thaker, T. Giordano, J. Williams, D. Rogers and K.K. Vasu, Bioorg. Med. Chem., 18, 2796 (2010).

23. D.S. Brown, J.G. Cumming, P. Bethel, J. Finlayson, S. Gerhardt, I. Nash, R.A. Pauptit, K.G. Pike, A. Reid, W. Snelson, S. Swallow and C. Thompson, Bioorg. Med. Chem. Lett., 22, 3879 (2012).

24. S.E. Abbas, F.M. Awadallah, N.A. Ibtahin, E.G. Said and G.M. Kamel, Eur. J. Med. Chem., 53, 141 (2012).

25. X. Gao, X. Cai, K. Yan, B. Song, L. Gao and Z. Chen, Molecules, 12, 2621 (2007).

26. Z. Wang, M. Wang, X. Yao, Y. Li, J. Tan, L. Wang, W. Qiao, Y. Geng, Y. Liu an Q. Wang, Eur. J. Med. Chem., 53, 275 (2012).

27. J.B. Koepfli, J.F. Mead and J.A. Brockman, J. Am. Chem. Soc., 71, 1049 (1949).

28. S. Zhu, J. Wang, G. Chandrashekar, E. Smith, X. Liu and Y. Zhang, Eur. J. Med. Chem., 45, 3864 (2010).

29. S. Zhu, G. Chandrashekar, L. Meng, K. Robinson and D. Chatterji, Bioorg. Med. Chem., 20, 927 (2012).

30. A.C. Glassser, L. Diamond and G. Combs, J. Pharm. Sci., 60, 127 (1971).

31. S.T.Al-Rashood, I.A. Aboldahab, M.N. Nagi, L.A. Abouzeid,A.A.M. AbdelAziz, S.G. Abdel-hamide, K.M. Youssef, A.M. Al-Obaid and H.I. ElSubbagh, Bioorg. Med. Chem., 14, 8608 (2006).

32. N.M. Abdel Gawad, H.H. Georgey, R.M. Youssef and N.A. El-Sayed, Eur. J. Med. Chem., 45, 6058 (2010).

33. P.S. Rrddy, P.P. Reddy and T. Vasantha, Heterocycl.-Sendai Then Tokyo, 60, 138 (2003).

34. M. Redondo, J.G. Zarruk, P. Ceballos, D.I. Pérez, C. Pérez, A. PerezCastillo, M.A. Moro, J. Brea, C. Val, M.I. Cadavid, M.I. Loza, N.E. Campillo, A. Martínez and C. Gil, Eur. J. Med. Chem., 47, 175 (2012).

35. I.M. EL-deen, S.M. Mohamed, M.M. Ismail and M. Abdel-Megid, Anal. Quim., 89, 621 (1993).

36. S.P. Hiremath, J.S. Biradar and S.M. Kudari, J. Indian Chem. Soc., 61, 74 (1984).

37. R.H. Khan, R.A. Srivastava and R.C. Rastogi, Indian J. Chem., 24B, 883 (1985)

38. J.R. Reid and N.D. Heindel, J. Heterocycl. Chem., 31, 925 (1976).

39. T. Shaikh, R. Rub, K. Bhise, R.B. Pimprikar and. A. Sufiyan, J. Pharm. Sci. Res., 2, 41 (2010).

40. B.P. Mallikarjuna, B.P. Mallikarjuna, B.S. Sastry, G.V. Suresh Kumar, Y. Rajendraprasad, S.M. Chandrashekar, K. Sathisha, Eur. J. Med. Chem., 44, 4739 (2009). 